\title{
Determining the Attitudes of Individuals Applying to Family Health Centre Towards the Methods They Applied in Pain Management
}

\author{
Aile Sağı̆̆ı̆ı Merkezine Bașvuran Bireylerin Ağrı Kontrolünde Uyguladıkları Yöntemlere Yönelik \\ Tutumlarının Belirlenmesi
}

\author{
Kenan Gumus', Seval Keloglan', Gonca Ustun', Zeliha Karapelıt² \\ ${ }^{1}$ Department of Nursing; ${ }^{2}$ Department of Midwifery, Faculty of Health Sciences, Amasya University, Amasya, Turkey
}

\begin{abstract}
Aim: Pain is an unpleasant sensory and emotional experience that has a varying prevalence in society and is controlled by using pharmacological or non-pharmacological methods. The purpose of this study was to determine the attitudes of individuals, who applied to the family health center (FHC), toward the use of analgesics and the non-pharmacological methods they applied for pain management.
\end{abstract}

Material and Method: The population of the study was composed of 572 individuals from 10 FHCs in the Amasya. The data were collected by a questionnaire consisting of three parts. The first part includes 9 questions investigating the sociodemographic characteristics, the second part includes 18 questions examining the attitudes of the participants toward the use of analgesics, and the third part includes 15 questions evaluating the non-pharmacological methods used by the participants for pain management. This research is a descriptive and cross-sectional study. In the data analysis, nominal variables were evaluated using frequency and percentage. Chi-square test was used to analyze qualitative data. The level of significance was accepted as 0.05 .

Results: The rates of using analgesics without prescription, and recommending effective analgesics for others, and the reading the prescription of analgesics were found to be high in many variables $(p<0.05)$. Hot-cold application $(52.9 \%)$, massage $(50 \%)$, and watching television (26.2\%) were the most commonly applied nonpharmacological pain management methods.

Conclusion: Individual, social and economic factors affect the use of analgesics. The rate of use of applications such as hot-cold application, massage, and watching television for pain management is high.

Key words: analgesia; pain management; family health center; non-pharmacological methods

\section{ÖZET}

Amaç: Ağrı, toplumda değișen bir yaygınlığa sahip olan ve farmakolojik veya farmakolojik olmayan yöntemler kullanılarak kontrol edilen hoș olmayan duyusal bir deneyimdir. Bu çalıșmada, aile sağı̆ğı merkezi (ASM)'ne bașvuran bireylerin ağrı kesici ilaç kullanımına yönelik tutumları ve ağrı kontrolünde uyguladıkları nonfarmakolojik yöntemleri belirlemek amaçlanmıștır.

Materyal ve Metot: On farklı ASM birimine kayıtı bireyler araștırmanın örneklemini olușturdu ( $n=572)$. Veriler, üç bölümden olușan soru formu vasıtasıyla toplanmıștır. Birinci kısımda katıımcıların sosyodemografik özelliklerini sorgulayan 9 soru, ikinci kısımda katılımcıların ağrı kesici ilaç kullanımına yönelik tutumlarını sorgulayan 18 soru, üçüncü kısımda ise katıımcıların ağrı kontrolünde uyguladıkları nonfarmakolojik yöntemleri sorgulayan 15 soru yer aldı. Bu araștırma, tanımlayıcı ve kesitsel tipte bir çalıșmadır. Veri analizinde nominal değișkenler frekans ve yüzde kullanılarak değerlendirildi. Nitel verilerin analizinde ki-kare testi kullanıldı. Anlamlılı düzeyi 0,05 olarak kabul edildi.

Bulgular: Reçetesiz ağrı kesici ilaç kullanan, kendisi için etkili olduğunu düșündügü ağrı kesici ilacı bașkasına öneren ve ilacın reçetesini okuyan kișilerde birçok değișkene göre anlamlı farklılı bulundu $(p<0,05)$. Masaj $(\% 50)$, sıcak-soğuk uygulama $(\% 52,9)$ ve televizyon seyretme $(\% 26,2)$ en fazla uygulanan nonfarmakolojik ağrı kontrol yöntemleri olarak belirlendi.

Sonuç: Bireysel, sosyal ve ekonomik faktörler ağrı kesici ilaç kulıanımı etkilemektedir. Ağrı kontrolünde masaj, sıcak-soğuk uygulama ve televizyon seyretme gibi uygulamaların kullanım oranı yüksektir.

Anahtar kelimeler: analjezi; ağrı yönetimi; aile sağlığı merkezi; nonfarmakolojik yöntemler

iletișim/Contact: Kenan Gumus, Department of Nursing, Faculty of Health Sciences, Amasya University, 05100, Amasya, Turkey • Tel:0544 7915549 • E-mail:kenan.gumus@amasya.edu.tr • Geliș/Received: 24.07.2020 • Kabul/Accepted: 11.01.2021

ORCID: Kenan Gümüs, 0000-0002-3582-6609 • Seval Keloğlan, 0000-0003-3533-7941 • Gonca Üstün, 0000-0003-3548-4351 • Zeliha Karapelit, 0000-0001-7751-645X 


\section{Introduction}

Pain is defined as an unpleasant sensory and emotional experience associated with actual or potential tissue damage ${ }^{1}$. Having a prevalence ranging between $1 \%$ and $60 \%$ in the society, pain appears as a physiological, psychological, social and economic problem ${ }^{2,3}$. Pain, which should be evaluated especially in the scope of primary healthcare services, is managed by using pharmacological or non-pharmacological methods 4 . However, it has been reported that pharmacological (analgesics) methods are frequently used for pain management ${ }^{5}$. The fast-acting and easy availability of analgesics can lead to the habit of unprescribed drug use upon recommendation ${ }^{6}$. In the literature, it is stated that analgesics are the leading non-prescription drugs bought without medical advice ${ }^{7}$. Different studies have reported that the rate of non-prescription analgesics varies between $34.3 \%$ and 62\% (8.9). In Turkey, 54.1\% of the non-prescribed drugs ${ }^{10}$ and $76.25 \%$ of the most common drugs at home ${ }^{11}$ are the analgesics. Many factors such as fast action, easy availability, and easy application of analgesics 5 are believed to affect attitudes toward the use of analgesics.

Tendency to non-pharmacological methods in pain management along with pharmacological methods is increasing ${ }^{3}$. Non-pharmacological methods are used either alone or in combination with pharmacological methods $5,12,13$. Non-pharmacological methods for pain management were applied in $49.1 \%$ and $42.4 \%$ of the patients in the studies conducted by Birge and Mollaoglu ${ }^{14}$ and Gungormus and Kiyak ${ }^{15}$, respectively. Non-pharmacological methods used for pain management include massage, meditation, acupuncture, hot-cold application, praying, menthol application on the skin, vibration, cognitive behavioral techniques, distraction, music listening, and the use of herbal remedies ${ }^{12,14,16-18}$.

In recent years, determining the application type and frequency of non-pharmacological methods frequently examined in nursing studies has been important in terms of raising awareness of individuals, family and society on this issue ${ }^{12,18}$. More importantly, the pain complaint is the main reason for seeking medical help from health institutions ${ }^{3}$ and this reveals the importance of gaining positive attitudes and behaviors toward the use of analgesics by individuals. Therefore, Family Health Centers (FHC), which are responsible for providing primary health care, have important responsibilities. It is of prime importance for FHCs to inform the society about the issues such as not taking medication upon recommendation, using the prescribed drugs, and taking drugs at the prescribed time and dose ${ }^{19}$. In this context, determining the existing problems related to the use of analgesics and offering solutions to these problems are believed to contribute to public health service. For this purpose, the attitudes of individuals, who applied to FHCs, toward analgesic use and non-pharmacological methods they applied for pain management were investigated in the study.

\section{Meterial and Method}

\section{Aim and Type of the Study}

This is a descriptive, cross-sectional, regional survey model and multi-center study. In this study, the answers to the following questions were sought.

- What are the attitudes of individuals, who applied to FHC, toward analgesic use?

- Are some attitudes toward the use of analgesics (the non-prescribed use of analgesics, recommending the effective analgesics to others, and reading the prescription of analgesics) affected by individual characteristics?

- What are the non-pharmacological methods used by individuals, who apply to FHC, for pain?

\section{Time, Place, Population and Sample}

The population of the study was composed of individuals who applied to 10 FHCs located in the Amasya. It was thought that collecting data from these FHCs would give an idea about the attitudes toward the use of analgesics and non-pharmacological methods used in this region. The sample was composed of 572 participants who applied to FHCs between February 2017 and May $2018(n=572)$. The questionnaire was carried out by the researchers.

\section{Inclusion Criteria}

The inclusion criteria of the study were determined as follows; being 18 years old and over, not using analgesics regularly, and agreeing to participate in the study.

\section{Data Collection Tool}

The data were collected using a questionnaire, prepared by the researchers upon the literature review ${ }^{13,18,19,20}$. The questionnaire consists of three parts. The first 
part includes 9 questions investigating the sociodemographic characteristics of the participants (age, gender, educational background, occupation, presence of chronic disease, etc., ). The second part includes 18 questions determining the attitudes of the participants toward the use of analgesics (the use of prescribed analgesics, place where the drug was bought, recommending the drug, keeping analgesics at home and in the bag constantly). The third part includes 15 questions examining the non-pharmacological methods applied by the participants for pain management (hot-cold application, plaster, distraction, praying, spa application, relaxation exercises, herbal mixture, etc.). Based on the results, the attitudes of the participants' toward the use of analgesics and their non-pharmacological methods for pain management were determined.

\section{Data Analysis and Evaluation}

The data obtained from the questionnaires were recorded to the database and analyzed by using the Statistical Package for the Social Sciences for Windows (SPSS 21.0, IBM Corp., Armonk, NY, USA) packaged software. In the data analysis, nominal variables were evaluated using frequency and percentage. Chi-square test was used to analyze qualitative data. The level of significance was accepted as 0.05 . In the power analysis performed to determine the power of the sample to represent the population, the medium effect size and the power at the significance level were 0.05 and 0.99 , respectively.

\section{Ethical Considerations}

All participants were informed about the aim and method of the study and signed informed consent. For the study, approval from the Ethics Committee (Number: 15386878-044) of Amasya University and the permissions from the provincial directorate of health were obtained.

\section{Results}

It was determined that $64.5 \%$ of the participants were married, 35.5\% had secondary school -high school education, and $39.9 \%$ were housewives. Also $54.5 \%$ of the participants had an income equal to expenses, $90.7 \%$ had social security, and $80.6 \%$ were residing in the city center. $70.6 \%$ of the participants had no chronic disease and it took 1-15 minutes for them to reach any health institution $(55.4 \%)$ or any pharmacy (59.1\%) (Table 1).
In individuals having less income than expenses, living in a village and/or town, and spending more than 45 minutes to reach any health institution or any pharma$c y$, the rate of nonprescribed analgesic use was higher $(p<0.05)$. The individuals, who were single, were literate, had no social security, resided in a village and/or town, and were spending at least 45 minutes to reach any health institution or any pharmacy, had a higher rate of recommending analgesics to others that they considered as effective $(p<0.05)$. The individuals, who were single, had undergraduate or graduate education level, were student, had an income more than expenses, a social security and no chronic disease.

The individuals, who were spending 1-15 minutes to reach any health institution or any pharmacy, had a higher rate of reading the prescription of analgesics $(\mathrm{p}<0.05)$ (Table 2).

It was determined that $32.7 \%$ of the participants believed that the analgesic treatment was the only solution for pain relief, $85.8 \%$ had analgesics at their home to be used in case of pain, $50.2 \%$ requested physician to prescribe additional analgesics for possibility of pain, and $44.2 \%$ were keeping analgesics at hand all the time. $78.7 \%$ used analgesics when they suffered from severe pain and $84.1 \%$ used analgesic tablets. The participants used analgesics mostly for headache (43.0\%). While $67.3 \%$ of the participants were using analgesics without prescription, $20.5 \%$ were using analgesics upon the recommendation of their relatives, friends or neighbors. $29.9 \%$ of the participants recommended the analgesics, they considered as effective, to others and the rate of those who bought analgesics from a pharmacy was very high $(96.5 \%)$. It was determined that $77.3 \%$ of the participants discontinued to use the medicine after the pain relieved and $42.1 \%$ disposed of the unused analgesics. While the rate of reading the prescription of the analgesics used was $64.0 \%$, the rate of being careful of the drug dose was $62.6 \%$. $49.0 \%$ of the participants were careful of the expiry date of analgesics (Table 3 ).

It was determined that $52.9 \%$ of the participants used hot-cold application, 50.0\% applied massage, 26.2\% watched television, $19.9 \%$ used menthol application, $19.4 \%$ used oral herbal mixture, and $7.0 \%$ applied herbal mixture to the pain region. Additionally, $17.7 \%$ of the participants suffering from pain applied relaxation exercises, $12.4 \%$ used praying, $12.2 \%$ chatted with others, $10.0 \%$ listened to music, $6.5 \%$ read books, $5.2 \%$ applied plaster, $5.2 \%$ used dreaming method, and $4.5 \%$ used spa application (Figure 1). 
Table 1. Comparison of the participants' socio-demographic characteristics with their answers to the analgesic use ( $n=572)$

\begin{tabular}{|c|c|c|c|c|c|c|c|c|c|c|c|c|c|c|}
\hline \multirow{3}{*}{$\begin{array}{l}\text { Sociodemographic } \\
\text { characteristics }\end{array}$} & \multirow[b]{3}{*}{$\mathrm{n}$} & \multirow[b]{3}{*}{$\%$} & \multicolumn{4}{|c|}{$\begin{array}{l}\text { Do you use analgesics without } \\
\text { prescription? }\end{array}$} & \multicolumn{4}{|c|}{$\begin{array}{c}\text { Do you recommend an analgesic, } \\
\text { which you considered as } \\
\text { effective, to others? }\end{array}$} & \multicolumn{4}{|c|}{$\begin{array}{c}\text { Do you read the prescription of } \\
\text { the analgesic you use? }\end{array}$} \\
\hline & & & \multicolumn{2}{|c|}{ Yes } & \multicolumn{2}{|c|}{ No } & \multicolumn{2}{|c|}{ Yes } & \multicolumn{2}{|c|}{ No } & \multicolumn{2}{|c|}{ Yes } & \multicolumn{2}{|c|}{ No } \\
\hline & & & $\mathrm{n}$ & $\%$ & $\mathrm{n}$ & $\%$ & $\mathrm{n}$ & $\%$ & $\mathrm{n}$ & $\%$ & $\mathrm{n}$ & $\%$ & $\mathrm{n}$ & $\%$ \\
\hline \multicolumn{15}{|l|}{ Marital status } \\
\hline $\begin{array}{l}\text { Married } \\
\text { Single }\end{array}$ & $\begin{array}{l}369 \\
203\end{array}$ & $\begin{array}{l}64.5 \\
35.5\end{array}$ & $\begin{array}{l}244 \\
141\end{array}$ & $\begin{array}{l}66.1 \\
69.5\end{array}$ & $\begin{array}{l}125 \\
62\end{array}$ & $\begin{array}{l}33.9 \\
30.5\end{array}$ & $\begin{array}{c}100 \\
71\end{array}$ & $\begin{array}{l}27.1 \\
35.0\end{array}$ & $\begin{array}{l}269 \\
132\end{array}$ & $\begin{array}{l}72.9 \\
65.0\end{array}$ & $\begin{array}{l}224 \\
142\end{array}$ & $\begin{array}{l}60.7 \\
69.9\end{array}$ & $\begin{array}{c}145 \\
61\end{array}$ & $\begin{array}{l}39.3 \\
30.1\end{array}$ \\
\hline $\mathrm{p}$ value & & & \multicolumn{4}{|c|}{$p=0.416, x^{2}: 0.661$} & \multicolumn{4}{|c|}{$\mathrm{p}=0.049, \mathrm{x}^{2}: 3.875$} & \multicolumn{4}{|c|}{$p=0.028 . x^{2}: 4.858$} \\
\hline \multicolumn{15}{|l|}{ Education level } \\
\hline $\begin{array}{l}\text { Literate } \\
\text { Primary school } \\
\text { Secondary-High school } \\
\text { Undergraduate and/or graduate }\end{array}$ & $\begin{array}{l}51 \\
130 \\
203 \\
188\end{array}$ & $\begin{array}{c}8.9 \\
22.7 \\
35.5 \\
32.9\end{array}$ & $\begin{array}{c}38 \\
97 \\
129 \\
121\end{array}$ & $\begin{array}{l}74.5 \\
74.6 \\
63.5 \\
63.4\end{array}$ & $\begin{array}{l}13 \\
33 \\
74 \\
67\end{array}$ & $\begin{array}{l}25.5 \\
25.4 \\
36.5 \\
36.6\end{array}$ & $\begin{array}{l}27 \\
47 \\
40 \\
57\end{array}$ & $\begin{array}{l}53.0 \\
36.2 \\
19.7 \\
30.3\end{array}$ & $\begin{array}{c}24 \\
83 \\
163 \\
131\end{array}$ & $\begin{array}{l}47.0 \\
63.8 \\
80.3 \\
69.7\end{array}$ & $\begin{array}{c}12 \\
71 \\
135 \\
148\end{array}$ & $\begin{array}{l}23.5 \\
54.6 \\
66.5 \\
78.7\end{array}$ & $\begin{array}{l}39 \\
59 \\
68 \\
40\end{array}$ & $\begin{array}{l}76.5 \\
45.4 \\
33.5 \\
22.3\end{array}$ \\
\hline $\mathrm{p}$ value & & & \multicolumn{4}{|c|}{$p=0.094, x^{2}: 6.404$} & \multicolumn{4}{|c|}{$\mathrm{p}<0.001, \mathrm{x}^{2}: 25.429$} & \multicolumn{4}{|c|}{$p<0.001, x^{2}: 59.454$} \\
\hline \multicolumn{15}{|l|}{ Occupation } \\
\hline $\begin{array}{l}\text { Housewife } \\
\text { Student } \\
\text { Farmer } \\
\text { Worker } \\
\text { Public employee } \\
\text { Private sector } \\
\text { Unemployed }\end{array}$ & $\begin{array}{l}228 \\
117 \\
25 \\
37 \\
89 \\
49 \\
27\end{array}$ & $\begin{array}{c}39.9 \\
20.5 \\
4.4 \\
6.5 \\
15.6 \\
8.6 \\
4.7\end{array}$ & $\begin{array}{l}146 \\
78 \\
20 \\
28 \\
61 \\
29 \\
23\end{array}$ & $\begin{array}{l}64.0 \\
66.7 \\
80.0 \\
75.7 \\
68.5 \\
59.2 \\
85.2\end{array}$ & $\begin{array}{c}82 \\
39 \\
5 \\
9 \\
28 \\
20 \\
4\end{array}$ & $\begin{array}{l}36.0 \\
33.3 \\
20.0 \\
24.3 \\
31.5 \\
40.8 \\
14.8\end{array}$ & $\begin{array}{c}70 \\
34 \\
8 \\
9 \\
26 \\
9 \\
15\end{array}$ & $\begin{array}{l}30.7 \\
29.0 \\
32.0 \\
24.3 \\
29.2 \\
18.4 \\
55.6\end{array}$ & $\begin{array}{l}158 \\
83 \\
17 \\
28 \\
63 \\
40 \\
12\end{array}$ & $\begin{array}{l}59.3 \\
71.0 \\
68.0 \\
75.7 \\
70.8 \\
81.6 \\
44.4\end{array}$ & $\begin{array}{l}141 \\
87 \\
8 \\
19 \\
64 \\
34 \\
13\end{array}$ & $\begin{array}{l}61.8 \\
74.3 \\
32.0 \\
51.3 \\
71.9 \\
69.3 \\
48.1\end{array}$ & $\begin{array}{l}87 \\
30 \\
17 \\
18 \\
25 \\
15 \\
14\end{array}$ & $\begin{array}{l}38.2 \\
25.7 \\
68.0 \\
48.7 \\
28.1 \\
30.7 \\
51.9\end{array}$ \\
\hline $\mathrm{p}$ value & & & \multicolumn{4}{|c|}{$p=0.143, x^{2}: 9.592$} & \multicolumn{4}{|c|}{$\mathrm{p}=0.055, \mathrm{x}^{2}: 12.320$} & \multicolumn{4}{|c|}{$p<0.001, x^{2}: 25.565$} \\
\hline \multicolumn{15}{|l|}{ Income level } \\
\hline $\begin{array}{l}\text { Less than expenses } \\
\text { Equal to expenses } \\
\text { More than expenses }\end{array}$ & $\begin{array}{c}179 \\
312 \\
81\end{array}$ & $\begin{array}{l}31.3 \\
54.5 \\
14.2\end{array}$ & $\begin{array}{l}136 \\
198 \\
51\end{array}$ & $\begin{array}{l}76.0 \\
63.5 \\
63.0\end{array}$ & $\begin{array}{c}43 \\
114 \\
30\end{array}$ & $\begin{array}{l}24.0 \\
36.5 \\
37.0\end{array}$ & $\begin{array}{l}62 \\
90 \\
19\end{array}$ & $\begin{array}{l}34.6 \\
28.5 \\
23.5\end{array}$ & $\begin{array}{l}117 \\
222 \\
62\end{array}$ & $\begin{array}{l}65.4 \\
71.5 \\
76.5\end{array}$ & $\begin{array}{c}98 \\
211 \\
57\end{array}$ & $\begin{array}{l}54.7 \\
67.6 \\
70.3\end{array}$ & $\begin{array}{c}81 \\
101 \\
24\end{array}$ & $\begin{array}{l}45.3 \\
32.4 \\
29.7\end{array}$ \\
\hline $\mathrm{p}$ value & & & \multicolumn{4}{|c|}{$\mathrm{p}=0.012, \mathrm{x}^{2}: 8.907$} & \multicolumn{4}{|c|}{$p=0.158, x^{2}: 3.686$} & \multicolumn{4}{|c|}{$p=0.007, x^{2}: 9.857$} \\
\hline \multicolumn{15}{|l|}{ Social security } \\
\hline $\begin{array}{l}\text { Yes } \\
\text { No }\end{array}$ & $\begin{array}{l}519 \\
53\end{array}$ & $\begin{array}{l}90.7 \\
9.3\end{array}$ & $\begin{array}{l}347 \\
38\end{array}$ & $\begin{array}{l}66.9 \\
71.7\end{array}$ & $\begin{array}{l}172 \\
15\end{array}$ & $\begin{array}{l}33.1 \\
28.3\end{array}$ & $\begin{array}{c}147 \\
24\end{array}$ & $\begin{array}{l}28.3 \\
45.2\end{array}$ & $\begin{array}{l}372 \\
29\end{array}$ & $\begin{array}{l}71.7 \\
54.8\end{array}$ & $\begin{array}{l}343 \\
23\end{array}$ & $\begin{array}{l}66.9 \\
43.3\end{array}$ & $\begin{array}{l}176 \\
30\end{array}$ & $\begin{array}{l}33.1 \\
56.7\end{array}$ \\
\hline$p$ value & & & \multicolumn{4}{|c|}{$p=0.474, x^{2}: 0.512$} & \multicolumn{4}{|c|}{$p=0.010, x^{2}: 6.600$} & & $=0.001$ & $2: 10.7$ & \\
\hline Place of residence & & & & & & & & & & & & & & \\
\hline $\begin{array}{l}\text { Village/Town } \\
\text { District center } \\
\text { City center }\end{array}$ & $\begin{array}{l}66 \\
45 \\
461\end{array}$ & $\begin{array}{c}11.5 \\
7.9 \\
80.6\end{array}$ & $\begin{array}{c}60 \\
21 \\
304\end{array}$ & $\begin{array}{l}91.0 \\
47.0 \\
66.0\end{array}$ & $\begin{array}{c}6 \\
24 \\
157\end{array}$ & $\begin{array}{c}9.0 \\
53.0 \\
34.0\end{array}$ & $\begin{array}{c}39 \\
16 \\
116\end{array}$ & $\begin{array}{l}59.0 \\
35.6 \\
25.1\end{array}$ & $\begin{array}{c}27 \\
29 \\
345\end{array}$ & $\begin{array}{l}41.0 \\
64.4 \\
74.9\end{array}$ & $\begin{array}{c}34 \\
29 \\
303\end{array}$ & $\begin{array}{l}51.5 \\
64.4 \\
65.7\end{array}$ & $\begin{array}{c}32 \\
16 \\
158\end{array}$ & $\begin{array}{l}48.5 \\
35.6 \\
34.3\end{array}$ \\
\hline $\mathrm{p}$ value & & & & $0<0.001$ & $2: 25.8$ & & & $<0.001$, & $2: 32.4$ & & & $=0.079$ & $x^{2}: 5.06$ & \\
\hline
\end{tabular}

Row percentages are used in the table; $n$, Number; \%, Percentage; $x^{2}$, Chi Square.

Table 2. Distribution of the times required for the participants to go to a health institution or pharmacy $(n=572)$

\begin{tabular}{|c|c|c|c|c|c|c|c|c|c|c|c|c|c|c|}
\hline \multirow{3}{*}{$\begin{array}{l}\text { Sociodemographic } \\
\text { characteristics }\end{array}$} & \multirow[b]{3}{*}{$\mathrm{n}$} & \multirow[b]{3}{*}{$\%$} & \multicolumn{4}{|c|}{$\begin{array}{l}\text { Do you use analgesics without } \\
\text { prescription? }\end{array}$} & \multicolumn{4}{|c|}{$\begin{array}{c}\text { Do you recommend an analgesic, } \\
\text { which you considered as } \\
\text { effective, to others? }\end{array}$} & \multicolumn{4}{|c|}{$\begin{array}{c}\text { Do you read the prescription of } \\
\text { the analgesic you use? }\end{array}$} \\
\hline & & & \multicolumn{2}{|c|}{ Yes } & \multicolumn{2}{|c|}{ No } & \multicolumn{2}{|c|}{ Yes } & \multicolumn{2}{|c|}{ No } & \multicolumn{2}{|c|}{ Yes } & \multicolumn{2}{|c|}{ No } \\
\hline & & & $\mathrm{n}$ & $\%$ & $\mathrm{n}$ & $\%$ & $\mathrm{n}$ & $\%$ & $\mathrm{n}$ & $\%$ & $\mathrm{n}$ & $\%$ & $\mathrm{n}$ & $\%$ \\
\hline \multicolumn{15}{|c|}{ State the time required to reach a health institution } \\
\hline $\begin{array}{l}1-15 \mathrm{~min} . \\
16-30 \mathrm{~min} . \\
31-45 \mathrm{~min} . \\
46-60 \mathrm{~min} .\end{array}$ & $\begin{array}{c}317 \\
176 \\
55 \\
24\end{array}$ & $\begin{array}{c}55.4 \\
30.8 \\
9.6 \\
4.2\end{array}$ & $\begin{array}{c}196 \\
122 \\
46 \\
21\end{array}$ & $\begin{array}{l}62.0 \\
69.0 \\
84.0 \\
88.0\end{array}$ & $\begin{array}{c}121 \\
54 \\
9 \\
3\end{array}$ & $\begin{array}{l}38.0 \\
31.0 \\
16.0 \\
12.0\end{array}$ & $\begin{array}{l}85 \\
51 \\
22 \\
13\end{array}$ & $\begin{array}{l}26.8 \\
28.9 \\
40.0 \\
54.1\end{array}$ & $\begin{array}{c}232 \\
125 \\
33 \\
11\end{array}$ & $\begin{array}{l}73.2 \\
71.1 \\
60.0 \\
45.9\end{array}$ & $\begin{array}{c}218 \\
108 \\
32 \\
8\end{array}$ & $\begin{array}{l}68.7 \\
61.3 \\
58.1 \\
33.3\end{array}$ & $\begin{array}{l}99 \\
68 \\
23 \\
16\end{array}$ & $\begin{array}{l}31.3 \\
38.7 \\
41.9 \\
66.7\end{array}$ \\
\hline $\mathrm{p}$ value & & & \multicolumn{4}{|c|}{$p=0.001, x^{2}: 15.758$} & \multicolumn{4}{|c|}{$p=0.012, x^{2}: 10.933$} & \multicolumn{4}{|c|}{$p=0.003, x^{2}: 14.263$} \\
\hline \multicolumn{15}{|c|}{ State the time required to reach a pharmacy } \\
\hline $\begin{array}{l}1-15 \text { min. } \\
16-30 \mathrm{~min} . \\
31-45 \min . \\
46-60 \mathrm{~min} .\end{array}$ & $\begin{array}{c}338 \\
140 \\
71 \\
23\end{array}$ & $\begin{array}{c}59.1 \\
24.5 \\
12.4 \\
4.0\end{array}$ & $\begin{array}{c}210 \\
95 \\
59 \\
21\end{array}$ & $\begin{array}{l}62.1 \\
68.0 \\
83.1 \\
91.3\end{array}$ & $\begin{array}{c}128 \\
45 \\
12 \\
2\end{array}$ & $\begin{array}{c}37.9 \\
32.0 \\
16.9 \\
8.7\end{array}$ & $\begin{array}{l}95 \\
39 \\
23 \\
14\end{array}$ & $\begin{array}{l}28.1 \\
27.8 \\
32.3 \\
60.8\end{array}$ & $\begin{array}{c}243 \\
101 \\
48 \\
9\end{array}$ & $\begin{array}{c}60.6 \\
25.2 \\
12.0 \\
2.2\end{array}$ & $\begin{array}{c}236 \\
86 \\
38 \\
6\end{array}$ & $\begin{array}{l}69.8 \\
61.4 \\
53.5 \\
26.0\end{array}$ & $\begin{array}{c}102 \\
54 \\
33 \\
17\end{array}$ & $\begin{array}{l}31.2 \\
38.6 \\
46.5 \\
74.0\end{array}$ \\
\hline
\end{tabular}

*, Orjinal ölçeğin (TCTRTÖ) Cronbach alfa'sı (Zeyneloğlu \& Terzioğlu, 2011). 
Table 3. Distribution of the participants' attitudes toward the use of analgesics

\begin{tabular}{|c|c|c|}
\hline Attitudes Toward the use of Analgesics & $\mathrm{n}$ & $\%$ \\
\hline \multicolumn{3}{|c|}{ Is the use of analgesics the only solution in case of pain? } \\
\hline Yes & 187 & 32.7 \\
\hline No & 385 & 67.3 \\
\hline \multicolumn{3}{|c|}{ Do you keep analgesics at home in case of pain? } \\
\hline Yes & 491 & 85.8 \\
\hline No & 81 & 14.2 \\
\hline \multicolumn{3}{|c|}{$\begin{array}{l}\text { Do you request physician to prescribe additional analgesic for possibility } \\
\text { of pain? }\end{array}$} \\
\hline Yes & 287 & 50.2 \\
\hline No & 285 & 49.8 \\
\hline \multicolumn{3}{|c|}{ Do you always keep analgesics in your purse, wallet or car? } \\
\hline Yes & 253 & 44.2 \\
\hline No & 319 & 55.8 \\
\hline \multicolumn{3}{|l|}{ When do you use analgesics? } \\
\hline Mild pain & 35 & 6.1 \\
\hline Severe pain & 450 & 78.7 \\
\hline Fever & 13 & 2.3 \\
\hline Feeling bad & 74 & \\
\hline \multicolumn{3}{|c|}{ Which form of analgesic do you usually use? } \\
\hline Tablet & 481 & 84.1 \\
\hline Injection & 91 & 15.9 \\
\hline \multicolumn{3}{|c|}{ For which pain type do you use analgesics mostly? } \\
\hline Headach & 246 & 43.0 \\
\hline Throat ache & 27 & 4.7 \\
\hline Back-neck pain & 97 & 17.0 \\
\hline Hand-arm-leg pain & 56 & 9.8 \\
\hline Abdominal pain & 30 & 5.2 \\
\hline Period pain & 66 & 11.5 \\
\hline Others & 50 & 8.8 \\
\hline \multicolumn{3}{|c|}{ Do you use analgesics without prescription? } \\
\hline Yes & 385 & 67.3 \\
\hline No & 187 & 32.7 \\
\hline \multicolumn{3}{|c|}{$\begin{array}{l}\text { Do you use analgesics with the recommendation of a friend, relative, or } \\
\text { neighbour? }\end{array}$} \\
\hline Yes & 117 & 20.5 \\
\hline No & 455 & 79.5 \\
\hline \multicolumn{3}{|c|}{ Do you recommend an analgesic, you consider as effective, to others? } \\
\hline Yes & 171 & 29.9 \\
\hline No & 401 & 70.1 \\
\hline \multicolumn{3}{|l|}{ Where do you get analgesics? } \\
\hline From a pharmacy & 552 & 96.5 \\
\hline From social circle & 20 & 3.5 \\
\hline \multicolumn{3}{|l|}{ When do you stop using analgesics? } \\
\hline When the pain relieves & 442 & 77.3 \\
\hline Once the disease has passed & 49 & 8.6 \\
\hline When the drug is over & 25 & 4.4 \\
\hline Upon the doctor's advice & 56 & 9.8 \\
\hline \multicolumn{3}{|c|}{$\begin{array}{l}\text { What do you do with analgesics that have been no longer used in your } \\
\text { home? }\end{array}$} \\
\hline I use them again when l'm sick & 222 & 38.8 \\
\hline I give them to the health institution & 62 & 10.8 \\
\hline I dispose of them & 241 & 42.1 \\
\hline I keep them & 47 & 8.2 \\
\hline \multicolumn{3}{|c|}{ Do you read the prescription of the analgesic you use? } \\
\hline Yes & 206 & 64.0 \\
\hline No & 366 & 36.0 \\
\hline \multicolumn{3}{|l|}{ Are you careful of the dose of analgesics? } \\
\hline Yes & 358 & 62.6 \\
\hline No & 214 & 37.4 \\
\hline \multicolumn{3}{|c|}{ Do you check the expiry date of analgesics before use? } \\
\hline I always pay attention & 280 & 49.0 \\
\hline I usually pay attention & 154 & 26.9 \\
\hline Sometimes I pay attention & 106 & 18.5 \\
\hline I do not pay attention & 32 & 5.6 \\
\hline Total & 572 & 100 \\
\hline
\end{tabular}

\section{Discussion}

In this study, analgesic use habits of individuals, who applied to FHC, and their non-pharmacological methods for pain management were investigated.

In case of disease, individuals are expected to consult a doctor for diagnosis and treatment, however sometimes they exhibit behaviors to treat the disease by themselves $^{21}$. Furthermore, buying and taking drugs without prescription are becoming a common problem in many countries ${ }^{7}$. In the literature, the studies on individuals' drug use habits have reported that the non-prescription drugs are mostly analgesics $7,10,19,22-25$. It was found in the present study that most of the participants $(67.3 \%)$ were using analgesics without prescription, which is compatible with the literature. In the studies conducted, factors such as income level, health insurance, health institution or pharmacy access time and time are among the reasons for the high rate of use of non-perpetrators ${ }^{6,20,26}$. Results suggest that the rate of non-prescription drug use is high. This results are believed to be associated with the fact that analgesics can be obtained without prescription, are easily accessible and are affordable. In this study, it was determined that individuals, having low income level, living in rural areas, and spending a long time on reaching any health institution or any pharmacy, had higher rates of non-prescribed use of analgesics. Based on these results, it is thought that financial difficulties and transportation-related factors may cause non-prescribed analgesic use.

The recommendation of the social circle increases people's tendency toward non-prescribed drug use ${ }^{22}$. Similar to the rate determined in the present study (20.5\%), the studies in the literature have revealed that analgesics are used in accordance with the recommendation of family members, neighbors, relatives, and friends ${ }^{19,22,24}$. Although this rate seems low, it is notable that it is vulnerable to abuse and is affected by many factors. In the present study, it was found that those who were single and had a low education level had a high rate of recommending the analgesics, which they considered as effective, to others. Other studies have also reported that students and singles recommend drugs to their circle at most and the rate of recommending the drug to an acquaintance, neighbor or friend is higher in those with low education level $\mathrm{l}^{10,19,24}$, which are compatible with the results of the present study. All results indicated that recommending analgesics was affected by the factors such as financial and social difficulties, marital status, education level, place of residence, and the distance to any health institution-pharmacy. 


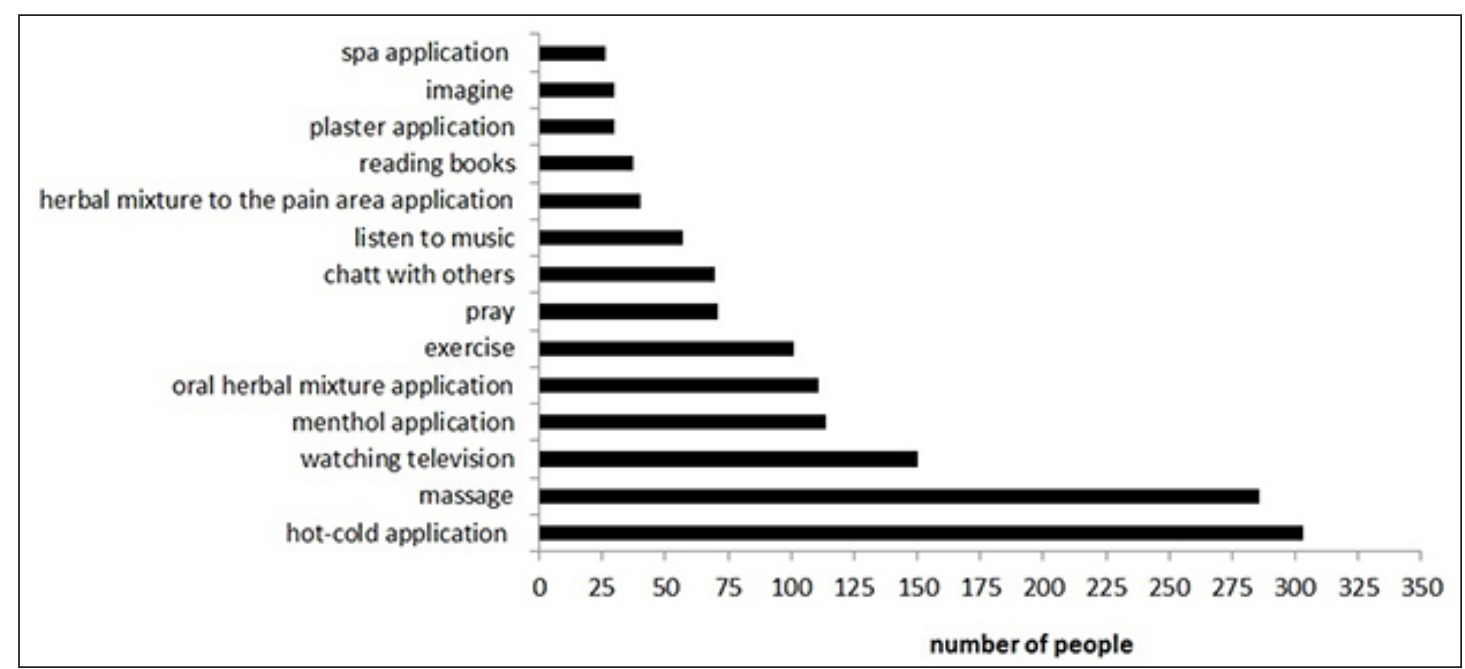

Figure 1. Distribution of non-pharmacological methods applied by the participants for pain management.

In Turkey, it is stated that the instructions for use of the drug are read significantly ${ }^{10,27}$. The rate of reading the prescription of analgesics (64.0\%) was also very high in the present study, which is compatible with the literature. The related studies revealed that the status of reading the prescription of drugs used was associated with the education level ${ }^{10,28}$. In this study, it was also determined that the education level affected the rate of reading the prescription of the drug used. However, in addition to the literature, other factors were found to affect this rate, as well. The factors determined in this study included being single, being a student, having income more than expenses, having a social security, having no chronic disease, living in a location near a pharmacy and health institution.

A great majority of the participants (67.3\%) stated that the use of analgesics was not a single solution for pain management. In addition, it was determined that they used several non-pharmacological methods for pain management. In the literature, it is stated that there has been a tendency toward many non-pharmacological methods for pain management ${ }^{29}$. Decreasing the rate of analgesic use, enhancing the quality of life of a patient by relieving the pain problem as much as possible, applying easily, without an economic burden to the individual positively affects the tendency toward non-pharmacological methods 5 . Gungormus and Kiyak $^{15}$ determined that $42.4 \%$ of individuals, who applied to FHC, used non-pharmacological methods for pain management. In the present study, it was found that the most common non-pharmacological pain management methods were hot-cold application $(52.9 \%)$, massage $(50 \%)$, and watching television (26.2\%). In the study by Birge and Mollaoglu ${ }^{14}$, they determined that hot-cold application (33.7\%), massage (23.7\%), herbal method (17.5\%) and distraction activities $(12.5 \%)$ were the non-pharmacological methods used to relieve pain which is similar with the present study ${ }^{14}$. In the study conducted by Gumus et al. ${ }^{30}$ to investigate the non-pharmacological pain management methods applied by healthcare professionals for pain management, hot-cold application (53.3\%) and distraction (42.2\%) methods were found to be applied mostly. Hot-cold application is stated to be effective for pain management because it is effective in reducing ischemic pain, removing metabolic residues, increasing the release of endogenous opioids, and relieving muscle spasm. Distraction applications such as watching television allow individuals to pay attention to what they like, increase pain tolerance, and elevate pain threshold ${ }^{5}$,

Consequently, the participants had a high rate of nonprescribed analgesic use. While the rate of reading the prescription of analgesics used was high, the rate of recommending the analgesics, considered as effective to others was relatively low. Some socio-demographic characteristics of the participants such as income status, marital status, place of residence, education level, social security, presence of chronic disease, and the distance of residence to a health institution or pharmacy were observed to affect the habits of analgesic use. The participants applied some non-pharmacological methods 
(hot-cold application, massage, watching TV. . .) at a high rate when they suffered from pain. The rates of using these methods varied.

According to these results, the following recommendations are made: FHCs have educational, protective, and follow-up roles for rational drug use. Their effectiveness should be increased by strengthening these roles. It is recommended to inform society regularly about the risks caused by the non-prescribed use of analgesics. FHCs are recommended to provide follow-up, surveillance, and counseling services regularly through home visits to the individuals whose access to healthcare services are adversely affected by their sociodemographic characteristics. The effective use of non-pharmacological pain management methods, whose effectiveness has been proved and which individuals can easily apply, through the correct technique should be encouraged.

\section{Conflict of Interest}

The authors report no conflicts of interest. Also, this study was not supported financially.

\section{References}

1. International Association for the Study of Pain (IASP). https:// www.iasp-pain.org/terminology ? navItem Number $=576$ : [accessed: 06.08.2019].

2. Henschke N, Kamper SJ, Maher CG. The epidemiology and economic consequences of pain. Mayo Clinic proceedings, 2015;90(1):139-47.

3. Peleg R, Liberman O, Press Y, Shvartzman P. Patients visiting the complementary medicine clinic for pain: A crosssectional study. BMC Complementary and Alternative Medicine, 2015;11:36.

4. Henderson JV, Harrison CM, Britt HC, Bayram CF, Miller GC. Prevalence, causes, severity, impact, and management of chronic pain in Australian general practice patients. Pain Medicine 2013;14(9):1346-61.

5. Ozveren H. Non-pharmacological methods at pain management. Hacettepe University Faculty of Health Sciences Nursing Journal 2011;18(1):83-92.

6. Pinar N. Pharmaceutical expenditures in our country. Journal of Inonu University Medical Faculty 2012;19(1):59-65.

7. Cooper RJ. Over-the-counter medicine abuse-a review of the literature. Journal of Substance Use 2013;18(2):82-107.

8. Mehuys E, Crombez G, Paemeleire K, Adriaens E, Hees TV, Demarche S. Self-medication with over-the-counter analgesics: A survey of patient characteristics and concerns about pain medication. The Journal of Pain 2019;20(2):215-23.
9. Tesfamariam, S., Anand, I. S., Kaleab, G., Berhane, S., Woldai, B., Habte, E. Self-medication with over the counter drugs, prevalence of risky practice and its associated factors in pharmacy outlets of Asmara, Eritrea. BioMed Central Public Health 2019;19(1):159.

10. Mete S, Unal Z. Determination of drug use habits of the residents of Cappadocia region provincial centers. Nevsehir Journal of Science and Technology 2017;6(2):661-80.

11. Beggi B, Asik Z. Evaluation of rational drug use in patients applying to family medicine out patient clinic. Ankara Medical Journal 2019;1:251-60.

12. Bayindir SK, Curuk GN. Examining nursing theses about complementary and alternative methods for pain management in Turkey. Journal of Education and Research in Nursing 2015;12(3):162-9.

13. Karadag E, Sevinc E. In painful situations the traditional practices applied by elderly people living in Tunceli. Spatula DD 2014;4(4):179-86.

14. Birge AO, Mollaoglu M. Pain beliefs of patients and the nonpharmacological methods they use to manage the pain. Agri 2018;30(2):84-92.

15. Gungormus Z, Kiyak E. Evaluation of the knowledge, attitude and behaviors of individuals who suffer from pain towards complementary and alternative medicines. Agri 2012;24(3):123-9.

16. Hicks H, Edeburn K, Mages MK. Non-pharmacological pain management interventions to decrease pharmacological need in a long-term carefacility: A quality improvement study. Celebrating Scholarship and Creativity Day https://digitalcommons.csbsju. edu/ur_cscday/66; 2019:66. [accessed: 24.07.2020].

17. Gemalmaz A. Use of complementary and alternative therapies in the management of pain. Turkiye Klinikleri Family MedicineSpecial Topics 2014;5(4):55-61.

18. Turan N, Ozturk A, Kaya N. A new responsibility in nursing: Complementary therapy. Maltepe University Journal of Nursing Science and Art 2010;3(1):93-98.

19. Yapici G, Balikci S, Ugur O. Attitudes and behavior of drug usage in applicants to primary health care center. Dicle Medical Journal 2011;38(4):458-65.

20. Karakurt P, Hacihasanoglu R, Yildirim A, Saglam R. Medication use among university students. TAF Preventive Medicine Bulletin 2019;9(5):505-12.

21. Dagtekin G, Demirtas Z, Alaiye M, Saglan R, Onsuz MF, Isikli $B$ et al. Rational drug use attitudes and behaviors of adults who apply for primary health care in semirural areas. Turkish World Implementation And Research Center Public Health Journal 2018;3(1):12-23.

22. Demiroglu T, Polat Y, Dogan U. Determination of behaviors and habits towards the usage of drugs of hospitalized adult patients in Kilis State Hospital. Gümüşhane University Journal Of Health Sciences 2017;6(1):93-98.

23. Gunes D, Kiyak E. The knowledge of the elderly on drug use and the evaluation of the factors affecting their knowledge level. Journal of Continuing Medical Education 2017;26(2):66-74. 
24. Ilhan MN, Aydemir O, Cakir M, Aycan S. A study in three districts of Ankara of behaviors associated with irrational use of drugs. Turkish Journal of Public Health 2014;12(3):188-200.

25. Turkey Ministry of Health Pharmaceutical Market Monitoring Report. Market position of the first 20 drugs in terms of sales volume and sales value. 2014. https://www.titck.gov.tr/ PortalAdmin/Uploads/Titck/Contents/Documents/;2014.

26. Ekim A, Akın İ, Ocakcı AF. Self medication among adolescents. ACU Health Sciences Journal 2018;9(3):272-276.

27. Ministry of Health Society's Perspective on Rational Drug Use, Research Series: 9. http://www.akilciilac.gov.tr/?p=328/2011; 2011 [accessed: 24.07.2020].
28. Pınar, N. Drug Usage Habits Of People In Adana. Çukurova University Faculty of Medicine Department of Medical Pharmacology Master Thesis, Adana, 2010.

29. Vaajoki A. We have to take pain definition, pain management, and the results of non-pharmacological studies seriously. Alternative \& Integrative Medicine 2013;2:134.

30. Gumus K, Musuroglu S, Ozlu ZK, Tascı O. Determining the use of nonpharmacologic methods by surgical nurses for postoperative pain management and the influencing professional factors: A multicenter study. Journal of Perianesthesia Nursing 2020;35(1):75-9. 